\title{
Yield and water use efficiency of cactus pear under arrangements, spacings and fertilizations
}

\author{
Alex A. Lédo ${ }^{1}$, Sérgio L. R. Donato ${ }^{1}$, Ignacio Aspiazú ${ }^{2}$, João A. da Silva ${ }^{1}$, \\ Paulo E. R. Donato ${ }^{1} \&$ Abner J. de Carvalho ${ }^{2}$ \\ ${ }^{1}$ Instituto Federal de Educação, Ciência e Tecnologia Baiano/Setor de Agricultura. Guanambi, BA, Brasil. E-mail: alex.ledo@ifbaiano.edu.br (Corresponding \\ author) - ORCID: 0000-0002-6176-6363; sergio.donato@ifbaiano.edu.br - ORCID: 0000-0002-7719-4662; joao.silva@ifbaiano.edu.br - ORCID: 0000- \\ 0001-5358-356X; paulo.donato@ifbaiano.edu.br - ORCID: 0000-0001-8696-8378 \\ ${ }^{2}$ Universidade Estadual de Montes Claros/Departamento de Ciências Agrárias. Janaúba, MG, Brasil. E-mail: ignacio.aspiazu@unimontes.br - ORCID: \\ 0000-0002-0042-3324; abner.carvalho@unimontes.br - ORCID: 0000-0002-6644-5307
}

\begin{abstract}
Cactus pear is adapted to semi-arid conditions. In this study, the objective was to evaluate the water use efficiency and green and dry mass yields of the cultivar Gigante under different fertilization rates and sources in three production cycles, spacing and planting arrangement. Seventy two treatments, involving two types of arrangements in the plots, three spacings in the subplots and 12 types of fertilization in the subsubplots were arranged in a split-split-plot scheme, using randomized block design with three repetions. Dry mass content decreases while water use efficiency and green mass and dry mass yields increase from the first to the third cycle. It is feasible to use planting arrangements in triple or quadrupling rows which allow increasing the mechanization index of the crop. Organomineral fertilization with 30 or $60 \mathrm{Mg} \mathrm{ha}^{-1}$ year $^{-1}$ of bovine manure combined with $150-300-600 \mathrm{~kg} \mathrm{ha}^{-1}$ year-1 of $\mathrm{N}-\mathrm{P}_{2} \mathrm{O}_{5}-\mathrm{K}_{2} \mathrm{O}$ and 300-300 $\mathrm{kg} \mathrm{ha}^{-1}$ year-1 of $\mathrm{P}_{2} \mathrm{O}_{5}-\mathrm{K}_{2} \mathrm{O}$, respectively; organic fertilization with $90 \mathrm{Mg} \mathrm{ha}^{-1}$ year-1 of manure; and mineral fertilization with $300-300-600 \mathrm{~kg} \mathrm{ha}^{-1}$ year ${ }^{-1}$ of $\mathrm{N}-\mathrm{P}_{2} \mathrm{O}_{5}-\mathrm{K}_{2} \mathrm{O}$ ensure green mass and dry mass yields greater than 200 and 15 $\mathrm{Mg} \mathrm{ha}^{-1} \mathrm{cycle}^{-1}$, respectively, and water use efficiency greater than $20 \mathrm{~kg} \mathrm{ha}^{-1} \mathrm{~mm}^{-1}$ in 'Gigante' cactus pear. It is concluded that yields of this magnitude are ensured with application of about 300-300-300 kg ha-1 year $^{-1}$ of $\mathrm{N}-\mathrm{P}_{2} \mathrm{O}_{5}-\mathrm{K}_{2} \mathrm{O}$ using organic, organomineral or mineral sources.
\end{abstract}

Key words: Opuntia, organomineral fertilization, bovine manure

\section{Produtividade e eficiência do uso da água da palma forrageira sob arranjos, espaçamentos e adubações}

RESUMO: A palma forrageira é adaptada às condições semiáridas. Neste trabalho, objetivou-se avaliar em três ciclos de produção, a eficiência do uso da água e as produtividades de massa verde e matéria seca, da cultivar Gigante sob diferentes doses e fontes de adubação, espaçamento e arranjos de plantas. Setenta e dois tratamentos, envolvendo dois arranjos nas parcelas, três espaçamentos nas subparcelas e 12 tipos de adubação nas sub-subparcelas foram dispostos em esquema de parcelas sub-subdivididas, em delineamento em blocos casualizados, com três repetições. O teor de matéria seca decresce e a eficiência do uso da água e as produtividades de massa verde e matéria seca aumentam do primeiro para o terceiro ciclo. É viável o uso de configurações de plantio em fileiras triplas ou quádruplas que possibilitam aumentar o índice de mecanização na cultura. As adubações organominerais com $30 \mathrm{ou} 60 \mathrm{Mg} \mathrm{ha}^{-1}$ ano $^{-1}$ de esterco bovino combinadas com 150-300-600 kg ha ${ }^{-1}$ ano ${ }^{-1}$ de N- $\mathrm{P}_{2} \mathrm{O}_{5}-\mathrm{K}_{2} \mathrm{O}$ e 300-300 $\mathrm{kg} \mathrm{ha}^{-1}$ ano ${ }^{-1}$ de $\mathrm{P}_{2} \mathrm{O}_{5}-\mathrm{K}_{2} \mathrm{O}$, respectivamente, adubação orgânica com $90 \mathrm{Mg} \mathrm{ha}^{-1}$ ano $^{-1}$ de esterco bovino e adubação mineral com 300-300-600 kg ha-1 ano ${ }^{-1}$ de $\mathrm{N}-\mathrm{P}_{2} \mathrm{O}_{5}-\mathrm{K}_{2} \mathrm{O}$ proporcionam produtividades de massa verde e de matéria seca maiores que 200 e $15 \mathrm{Mg} \mathrm{ha}^{-1}$ ciclo $^{-1}$, respectivamente, e eficiência de uso da água maior que $20 \mathrm{~kg} \mathrm{ha}^{-1} \mathrm{~mm}^{-1} \mathrm{em}$ palma forrageira 'Gigante'. Conclui-se que produtividades dessa ordem são asseguradas com aplicação de cerca de 300-300-300 kg ha' ano $^{-1}$ de $\mathrm{N}-\mathrm{P}_{2} \mathrm{O}_{5}-\mathrm{K}_{2} \mathrm{O}$ com fontes orgânica, organomineral ou mineral.

Palavras-chave: Opuntia, adubação organomineral, esterco bovino 


\section{INTRODUCTION}

The selection of a production system for cactus pear must consider some points, such as the socioeconomic condition of the producer, production costs (Donato et al., 2017a), possibility of mechanization (Padilha Junior et al., 2016), soil fertility, credit availability, and cultivar (Silva et al., 2010).

Cactus pear is adapted to semi-arid conditions because it withstands long drought periods. This adaptation involves many morphophysiological aspects, such as the Crassulacean Acid Metabolism (CAM) (Pimienta-Barrios et al., 2012), whose main advantage is the closure of stomata during daytime, which reduces excessive water loss through transpiration, although there may be losses of yield.

Cultivation techniques used for cactus pear such as increased planting density (Cavalcante et al., 2014), organic fertilization (Donato et al., 2014a), or mineral fertilization (Silva et al., 2016) can enhance its growth, dry mass yield and water use efficiency. This contradicts the idea that plants with CAM metabolism are little productive (Donato et al., 2017c).

Planting arrangements in triple or quadruple rows can increase the mechanization index of the crop (Padilha Junior et al., 2016), because it allows the use of mechanized or animal traction for fertilization, spraying and harvesting (Donato et al., 2017b).

There are several studies involving planting density (Sales et al., 2013; Cavalcante et al., 2014; Silva et al., 2014), spacings (Ramos et al., 2011), organic fertilization (Donato et al., 2014a), chemical fertilization (Silva et al., 2016) and organomineral fertilization (Padilha Junior et al., 2016). However, since it is a perennial crop with long cycle, 10 years or more (Donato et al., 2017b), the adopted production system is essential for its production longevity. This justifies the conduction of studies which consider different types of fertilization, planting arrangements and spacings, and also contemplating more production cycles, particularly until crop stabilization. Thus, this study aimed to evaluate for three production cycles the water use efficiency and green mass and dry mass yields of cactus pear cv. Gigante under different doses and sources of fertilization, spacing and planting arrangements.

\section{Material ANd Methods}

The experiment was carried out for three production cycles at the Instituto Federal Baiano, Campus of Guanambi, Bahia state, Brazil, in Oxisols, with weak A horizon, medium texture, flat to gently undulating relief. The coordinates are $14^{\circ}$ $13^{\prime} 30^{\prime \prime} \mathrm{S}, 42^{\circ} 46^{\prime} 53^{\prime \prime} \mathrm{W}$, at altitude of $545 \mathrm{~m}$, and Aw climate according to Köppen's classification, with mean annual rainfall and temperature of $680 \mathrm{~mm}$ and $26^{\circ} \mathrm{C}$, respectively.

In the first production cycle, with duration of 650 days from planting to harvest, conducted between October 2011 and July 2013, rainfall was equal to $912.27 \mathrm{~mm}$, corresponding to two rainy seasons - between October 2011 and February $2012(442.67 \mathrm{~mm})$, and between October 2012 and April $2013(469.62 \mathrm{~mm})$. In the second cycle, with duration of 330 days between two consecutive harvests, from August 2013 to July 2014, rainfall was equal to $853.96 \mathrm{~mm}$. In the third cycle, with duration of 330 days, between August 2014 and July 2015 , rainfall was $879.60 \mathrm{~mm}$. The data were recorded in an automatic meteorological station installed in the experimental area (Figure 1).

Treatments were arranged in split-split-plot scheme with two planting arrangements (triple and quadruple rows) in the plots; three spacings $S_{1}(3.00 \times 1.00 \times 0.25 \mathrm{~m}), \mathrm{S}_{2}(3.00 \times 1.00$ $\mathrm{x} 0.16 \mathrm{~m})$ and $\mathrm{S}_{3}(3.00 \times 1.00 \times 0.125 \mathrm{~m})$ in the subplots; and 12 types of fertilization, Manure $\left(\mathrm{Mg} \mathrm{ha}^{-1}\right)-\mathrm{N}-\mathrm{P}_{2} \mathrm{O}_{5}-\mathrm{K}_{2} \mathrm{O}\left(\mathrm{kg} \mathrm{ha}^{-1}\right)$ : 1) $0-000-000-000$; 2) $0-300-300-300$; 3) $0-300-300-600$; 4) $30-000-000-000$; 5) 30-150-300-300; 6) 30-150-300-600; 7) 60-000-000-000; 8) 60-000-300-300; 9) 60-000-300-600; 10) 90-000-000-000; 11) 90-000-000-300; and 12) 90-000-000-600 in the sub-subplots. Fertilizations were carried out in the year of planting and in the rainy seasons of the cycles.

Bovine manure doses of 30,60 and $90 \mathrm{Mg} \mathrm{ha}^{-1}$ respectively supply the soil with $130-270-75 ; 260-540-150$ and 390-810$225 \mathrm{~kg} \mathrm{ha}^{-1}$ of $\mathrm{N}-\mathrm{P}_{2} \mathrm{O}_{5}-\mathrm{K}_{2} \mathrm{O}$, per application. The manure used has $\mathrm{OM}=63.73 \mathrm{~g} \mathrm{~kg}^{-1}$, ashes $=36.27 \mathrm{dag} \mathrm{kg}{ }^{-1}$, total carbon $=$ $29.98 \mathrm{dag} \mathrm{kg}^{-1}$ and $\mathrm{pH}=7.42$ - Official Method of the Ministry of Agriculture (Brasil, 2007); moisture on dry basis at $65^{\circ} \mathrm{C}$ $=16.72 \%$; contents of macronutrients: $\mathrm{Ca}, \mathrm{Mg}, \mathrm{K}, \mathrm{N}$ and $\mathrm{S}$ $1.7,0.2,2.5,5.2$ and $2.3 \mathrm{~g} \mathrm{~kg}^{-1}$, respectively (EPA 3051/APHA $3120 \mathrm{~B}$ ), in this order, $\mathrm{P}=4.7 \mathrm{~g} \mathrm{~kg}^{-1}$ (APHA $4500-\mathrm{PC}$ ); contents of micronutrients (EPA 3051/APHA 3120B): B, Cu, Zn, Mn and

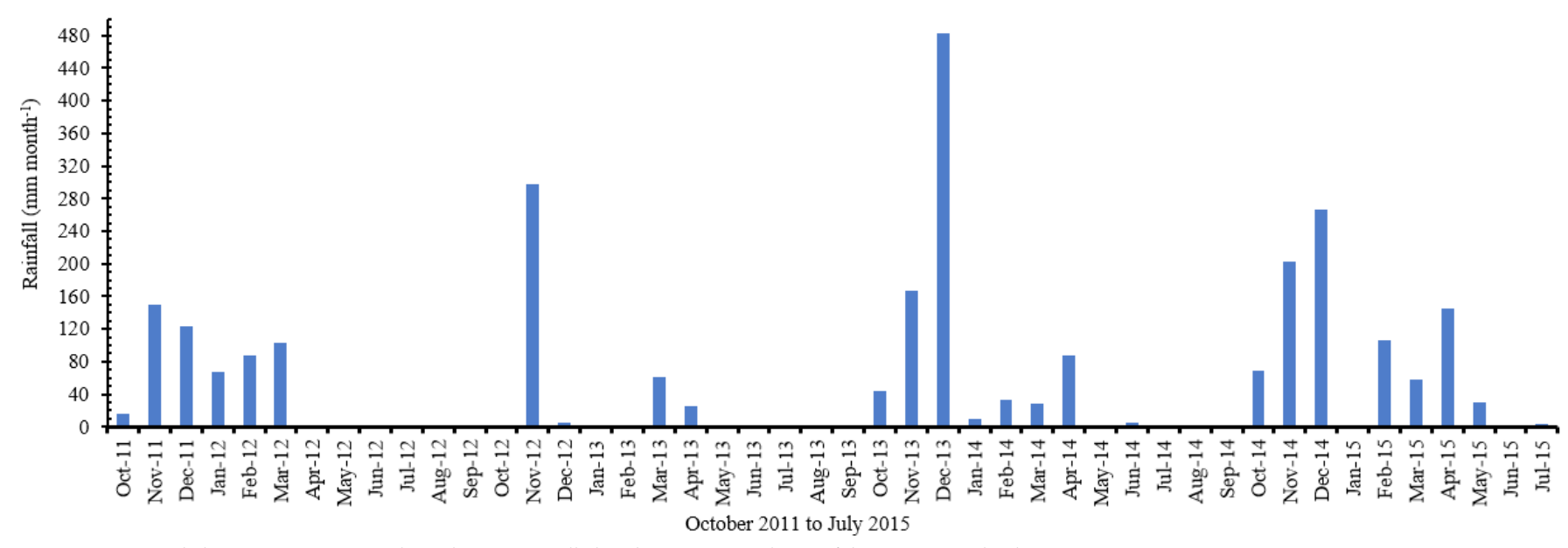

Source: Data recorded in automatic meteorological station installed in the experimental area of the Instituto Federal Baiano

Figure 1. Monthly rainfall along the experimental period

R. Bras. Eng. Agríc. Ambiental, v.23, n.6, p.413-418, 2019. 
$\mathrm{Fe}-2.1,45.2,200.5,391.8$ and $1,932.4 \mathrm{mg} \mathrm{kg}^{-1}$, respectively; and density of $0.38 \mathrm{~g} \mathrm{~cm}^{-3}$.

The sources used as mineral fertilizer were: ammonium sulfate $\left(\mathrm{NH}_{4}\right)_{2} \mathrm{SO}_{4}(20 \% \mathrm{~N} ; 24 \% \mathrm{~S})$, single superphosphate, $\mathrm{Ca}\left(\mathrm{H}_{2} \mathrm{PO}_{4}\right)_{2} 2 \mathrm{H}_{2} \mathrm{O},\left(18 \% \mathrm{P}_{2} \mathrm{O}_{5} ; 12 \% \mathrm{~S} ; 18 \% \mathrm{Ca}\right)$ and potassium chloride, $\mathrm{KCL}$, (58\% of $\mathrm{K}_{2} \mathrm{O} ; 45 \%$ of $\mathrm{Cl}$ ). Nitrogen and potassium were split into two applications, carried out at the beginning and middle of the rainy season of each cycle.

Prior to planting, the soil was sampled for chemical and textural characterization: Sandy Clay Loam texture; $\mathrm{pH}=5.57 ; \mathrm{OM}=1.13$ dag $\mathrm{kg}^{-1} ; \mathrm{P}=23.57 \mathrm{mg} \mathrm{dm}^{-3}$ and $\mathrm{K}=0.46 \mathrm{cmol}_{\mathrm{c}} \mathrm{dm}^{-3} ; \mathrm{Na}=0.10$; $\mathrm{Ca}$ $=1.93 ; \mathrm{Mg}=0.87$ and $\mathrm{H}+\mathrm{Al}=1.63\left(\mathrm{cmol} \mathrm{dm}^{-3}\right) ; \mathrm{B}=0.40 ; \mathrm{Cu}=$ $0.40 ; \mathrm{Zn}=2.03 ; \mathrm{Fe}=35.93$ and $\mathrm{Mn}=50.2\left(\mathrm{mg} \mathrm{dm}^{-3}\right) ; \mathrm{SB}=3.40$; effective CEC $=3.40$ and $\mathrm{CEC}$ at $\mathrm{pH} 7.0=4.97\left(\mathrm{cmol} \mathrm{dm}^{-3}\right) ; \mathrm{V}=$ 67.67\%; Prem $=39.10 \mathrm{mg} \mathrm{L}^{-1}$ and $\mathrm{EC}=0.93 \mathrm{dS} \mathrm{m}^{-1}$.

Preparation of the area consisted of cleaning, subsoiling, plowing and harrowing, opening of furrows with three- and four-row furrower regulated for $1.00 \mathrm{~m}$ between furrows and mean depth of $0.30 \mathrm{~m}$. Planting was carried out using one cladode per hole, in the vertical position, with the cut side facing up and $50 \%$ of its height buried into the ground. Fertilizations applied at planting followed the treatments. Cultivation practices were similar to those described by Silva et al. $(2012,2013)$ and Donato et al. (2014a, b).

At 650 days after planting (DAP), the first harvest was carried out and the structural characteristics of cactus pear were measured in the four central plants of each plot. The following characteristics were evaluated: plant height $(\mathrm{PH})$, number of cladodes per plant (NCL), cladode length (CLL), cladode width (CLW) and cladode area index (CAI). The first harvest was carried out in July 2013, and it was repeated in the subsequent cycles, with period of 330 days between them, July 2014 for the second cycle and July 2015 for the third cycle.

A tape was used to measure plant height, as the distance from the soil to the tip of the highest cladode; for cladode width and length, the region of greatest width and length were considered. Cladode area index (CAI) was estimated as the ratio between the total cladode area of the plant (Pinto et al., 2002) and the area occupied by the plant in the soil, represented by the spacing.

Dry mass content (DM) was determined by method proposed by Silva \& Queiroz (2009). At harvest, primary cladodes were preserved (Silva et al., 2012). All plants in the useful plot were collected to determine green mass yield (GMY), $\mathrm{Mg} \mathrm{ha}^{-1} \mathrm{cycle}^{-1}$. Dry mass yield (DMY) was estimated based on GMY and DM content. Water use efficiency $\left(\mathrm{kg} \mathrm{ha}^{-1} \mathrm{~mm}^{-1}\right)$ was calculated based on DM yield and on the rainfall recorded in each period (Figure 1).

The data of the evaluated characteristics were subjected to analysis of variance for each cycle. Significant interactions were further analyzed and, subsequently, means of fertilizations were grouped by the Scott-Knott criterion $(p<0.05)$, whereas means of arrangements and spacings were compared by Tukey test $(\mathrm{p}<0.05)$.

\section{Results AND Discussion}

The analysis of variance revealed that, for the number of cladodes, in the first cycle, cladode length and dry mass content, in the third cycle, of cactus pear cv. Gigante, there was interaction $(\mathrm{p}<0.05)$ between fertilization and spacing whereas the structural characteristics cladode length, cladode width, plant height, cladode area index, dry mass content and yield varied independently with spacings. Dry mass content (DM), dry mass yield (DMY) and rainwater productivity based on dry mass varied with the fertilizations, regardless of the planting arrangements and spacings.

In the first cycle, for the number of cladodes two groups were formed between the fertilizations according to the ScottKnott criterion $(\mathrm{p}<0.05)$ at the spacings $\mathrm{S}_{1}(3.0 \times 1.0 \times 0.25 \mathrm{~m})$ and $S_{3}(3.0 \times 1.0 \times 0.125 \mathrm{~m})$ with lowest values in the absence of fertilization at the spacing $S_{1}$ and in the absence of mineral fertilization and fertilization with $30 \mathrm{Mg} \mathrm{ha}^{-1}$ of manure at the spacing $\mathrm{S}_{3}$ (Table 1 ).

Between spacings there were differences by Tukey test $(\mathrm{p}<0.05)$ for the number of cladodes in all organic and

Table 1. Structural characteristics and dry mass content of cactus pear cv. Gigante cultivated under different fertilizations and spacings in the first and third production cycles

\begin{tabular}{|c|c|c|c|c|c|c|c|c|c|}
\hline \multirow{4}{*}{$\begin{array}{l}\text { Treatments } \\
\text { Fertilizations }\end{array}$} & \multicolumn{9}{|c|}{ Characteristics evaluated } \\
\hline & \multicolumn{5}{|c|}{ Cycle I - 2011-2013 } & \multicolumn{4}{|c|}{ Cycle III - 2014-2015 } \\
\hline & \multicolumn{3}{|c|}{ Number of cladodes } & \multicolumn{3}{|c|}{ Cladode length (cm) } & \multicolumn{3}{|c|}{ Dry mass content ( $\left.\mathrm{g} \mathrm{kg}^{-1}\right)$} \\
\hline & $\overline{\boldsymbol{S}_{1}}$ & $\mathrm{~S}_{2}$ & $\mathcal{S}_{3}$ & $S_{1}$ & $S_{2}$ & $S_{3}$ & $\overline{\mathcal{S}_{1}}$ & $S_{2}$ & $\overline{S_{3}}$ \\
\hline 1 & $12.3 \mathrm{~B} \mathrm{a}$ & $9.5 \mathrm{~B} \mathrm{a}$ & $8.5 \mathrm{~B} \mathrm{a}$ & $28.5 \mathrm{~B} \mathrm{~b}$ & $32.0 \mathrm{~A} \mathrm{a}$ & $27.2 \mathrm{~B} \mathrm{~b}$ & $79.7 \mathrm{~A} \mathrm{a}$ & $64.6 \mathrm{~B} \mathrm{~b}$ & $68.9 \mathrm{Bab}$ \\
\hline 2 & $18.7 \mathrm{Aa}$ & $15.5 \mathrm{~A} \mathrm{a}$ & $13.7 \mathrm{~A} \mathrm{a}$ & $32.2 \mathrm{~A} \mathrm{a}$ & $32.2 \mathrm{~A} \mathrm{a}$ & $33.0 \mathrm{Aa}$ & $72.4 \mathrm{~A} \mathrm{a}$ & $61.5 \mathrm{Ba}$ & $70.6 \mathrm{Aa}$ \\
\hline 3 & $21.6 \mathrm{~A} \mathrm{a}$ & $14.0 \mathrm{~A} \mathrm{~b}$ & $13.0 \mathrm{Ab}$ & $32.1 \mathrm{~A} \mathrm{a}$ & $32.7 \mathrm{~A} \mathrm{a}$ & $32.8 \mathrm{~A} \mathrm{a}$ & $84.1 \mathrm{~A}$ a & $63.5 \mathrm{~B} \mathrm{~b}$ & $76.1 \mathrm{~A} \mathrm{a}$ \\
\hline 4 & $17.0 \mathrm{Aa}$ & 13.6 Aab & 9.7 B b & $30.6 \mathrm{Ab}$ & $33.9 \mathrm{~A} \mathrm{a}$ & $33.0 \mathrm{Aab}$ & $66.7 \mathrm{~B} \mathrm{a}$ & $67.9 \mathrm{~A} \mathrm{a}$ & $68.1 \mathrm{~B} \mathrm{a}$ \\
\hline 5 & $17.7 \mathrm{~A} \mathrm{a}$ & $16.9 \mathrm{~A} \mathrm{a}$ & $14.7 \mathrm{~A} \mathrm{a}$ & $32.6 \mathrm{~A} \mathrm{a}$ & $32.3 \mathrm{~A} \mathrm{a}$ & $33.3 \mathrm{~A} \mathrm{a}$ & $65.0 \mathrm{~B} \mathrm{a}$ & $71.0 \mathrm{~A} \mathrm{a}$ & $69.3 \mathrm{~B} \mathrm{a}$ \\
\hline 6 & $19.3 \mathrm{~A} \mathrm{a}$ & $15.5 \mathrm{~A} \mathrm{a}$ & $14.3 \mathrm{~A} \mathrm{a}$ & $31.4 \mathrm{~A} \mathrm{~b}$ & $33.4 \mathrm{Aab}$ & $34.1 \mathrm{~A} \mathrm{a}$ & $68.2 \mathrm{~B} \mathrm{a}$ & $67.2 \mathrm{~B} \mathrm{a}$ & $68.1 \mathrm{~B} \mathrm{a}$ \\
\hline 7 & $20.3 \mathrm{~A} \mathrm{a}$ & $11.6 \mathrm{~A} \mathrm{~b}$ & $10.2 \mathrm{Ab}$ & $31.7 \mathrm{~A} \mathrm{a}$ & $33.4 \mathrm{~A} \mathrm{a}$ & $33.4 \mathrm{~A} \mathrm{a}$ & $65.2 \mathrm{~B} \mathrm{a}$ & $69.8 \mathrm{~A} \mathrm{a}$ & $62.6 \mathrm{~B} \mathrm{a}$ \\
\hline 8 & $18.8 \mathrm{Aa}$ & $16.7 \mathrm{~A} \mathrm{a}$ & $11.0 \mathrm{Ab}$ & $31.9 \mathrm{~A} \mathrm{a}$ & $34.1 \mathrm{~A} \mathrm{a}$ & $32.9 \mathrm{~A} \mathrm{a}$ & $67.1 \mathrm{~B} \mathrm{a}$ & $77.5 \mathrm{~A} \mathrm{a}$ & $70.8 \mathrm{~A} \mathrm{a}$ \\
\hline 9 & $19.0 \mathrm{~A} \mathrm{a}$ & 14.1 Aab & $11.7 \mathrm{Ab}$ & $31.1 \mathrm{~A} \mathrm{a}$ & $34.1 \mathrm{~A} \mathrm{a}$ & $33.5 \mathrm{~A} \mathrm{a}$ & $61.0 \mathrm{~B} \mathrm{a}$ & $61.6 \mathrm{~B} \mathrm{a}$ & $62.2 \mathrm{~B} \mathrm{a}$ \\
\hline 10 & $21.9 \mathrm{~A} \mathrm{a}$ & $13.4 \mathrm{Ab}$ & $10.5 \mathrm{Ab}$ & $32.7 \mathrm{~A} \mathrm{a}$ & $34.1 \mathrm{~A} \mathrm{a}$ & $34.1 \mathrm{~A} \mathrm{a}$ & $72.1 \mathrm{~A} \mathrm{a}$ & $72.3 \mathrm{~A} \mathrm{a}$ & $64.1 \mathrm{~B} \mathrm{a}$ \\
\hline 11 & $18.7 \mathrm{~A} \mathrm{a}$ & 14.4 Aab & $12.1 \mathrm{Ab}$ & $31.0 \mathrm{~A} \mathrm{a}$ & $33.7 \mathrm{~A} \mathrm{a}$ & $33.1 \mathrm{~A} \mathrm{a}$ & $68.3 \mathrm{~B} \mathrm{a}$ & $60.0 \mathrm{~B} \mathrm{a}$ & $66.1 \mathrm{~B} \mathrm{a}$ \\
\hline 12 & $18.9 \mathrm{~A} \mathrm{a}$ & 13.7 Aab & $12.6 \mathrm{Ab}$ & $31.6 \mathrm{Ab}$ & $35.1 \mathrm{~A} \mathrm{a}$ & $34.7 \mathrm{~A} \mathrm{a}$ & $70.8 \mathrm{~A} a$ & $72.4 \mathrm{~A} \mathrm{a}$ & $70.2 \mathrm{~A} \mathrm{a}$ \\
\hline CV (\%) & & 17.60 & & & 5.58 & & & 13.26 & \\
\hline
\end{tabular}

Fertilization: $\left(\mathrm{Mg} \mathrm{ha}^{-1}\right)$ of bovine manure - N-P O-K $\mathrm{K}_{2}\left(\mathrm{~kg} \mathrm{ha}^{-1}\right)$, (1) - 0-000-000-000; (2) - 0-300-300-300; (3) - 0-300-300-600; (4) - 30-000-000-000; (5) - 30-150-000-300; (6) - 30150-300-600; (7) - 60-000-000-000; (8) - 60-000-300-300; (9) - 60-000-300-600; (10) - 90-000-000-000; (11) - 90-000-000-300; (12) - 90-000-000-600

Means followed by the same uppercase letters in the column for fertilizations belong to the same group according to the Scott-Knott criterion ( $\mathrm{p}<0.05)$ and means followed by the same lowercase letters in the row for spacings did not differ significantly by Tukey test $(\mathrm{p}<0.05)$; Spacings: $\mathrm{S}_{1}-(3.0 \times 1.0 \times 0.2 \mathrm{~m}) ; \mathrm{S}_{2}-(3.0 \times 1.0 \times 0.16 \mathrm{~m}) ; \mathrm{S}_{3}-(3.0 \times 1.0 \times 0.125 \mathrm{~m})$ 
organomineral fertilizations with more than $60 \mathrm{Mg} \mathrm{ha}^{-1}$ of manure. In general, highest number of cladodes occurred in fertilization with greater supply of nutrients, especially at less dense spacings $S_{1}(3.0 \times 1.0 \times 0.25 \mathrm{~m})$, corroborating Donato et al. (2014a) and Silva et al. (2016).

In the third cycle, two groups were formed between fertilizations, at the spacings $S_{1}(3.0 \times 1.0 \times 0.25 \mathrm{~m})$ and $\mathrm{S}_{3}(3.0$ $\times 1.0 \times 0.125 \mathrm{~m})$ for cladode length and at $S_{2}(3.0 \times 1.0 \times 0.16 \mathrm{~m})$ and $\mathrm{S}_{3}$ for DM content (Table 1).

Interaction between spacing and fertilization for cladode length was found by Barros et al. (2016), despite being considered as a characteristic little influenced by management, with higher genotypic dependence (Mondragón Jacobo \& Pérez-Gonzáles, 2001), with greater dimension in primary cladode and decreasing as other orders appear (Silva et al., 2010). Cladode length was smaller in the absence of fertilization at both spacings, as found by Barros et al. (2016).

Among spacings there were differences for cladode length in the absence of fertilization, with highest values at spacing $\mathrm{S}_{2}$, in the fertilization with $30 \mathrm{Mg} \mathrm{ha}^{-1}$ of manure, with higher value at $S_{2}$ compared to $S_{1}$, in the organomineral fertilization with $30 \mathrm{Mg} \mathrm{ha}^{-1}$ of manure combined with 150-300-600 $\mathrm{kg} \mathrm{ha}^{-1}$ of $\mathrm{N}-\mathrm{P}_{2} \mathrm{O}_{5}-\mathrm{K}_{2} \mathrm{O}$, with higher value for $\mathrm{S}_{3}$ compared to $\mathrm{S}_{1}$, and in the organomineral fertilization with $90 \mathrm{Mg} \mathrm{ha}^{-1}$ of manure combined with $600 \mathrm{~kg} \mathrm{ha}^{-1}$ of $\mathrm{K}_{2} \mathrm{O}$, with lowest value at the spacing $\mathrm{S}_{1}$.

Higher dry mass contents were found at the spacing $S_{1}$, in the absence of fertilization and in the fertilizations with greater supply of nutrient, mineral and organic with $90 \mathrm{Mg} \mathrm{ha}^{-1}$. At the other spacings there was no pattern of variation with nutrient supply, which is corroborated by Donato et al. (2014b). Between spacings, there were differences for DM in the absence of fertilization, with higher values at spacing $S_{1}$ compared to $\mathrm{S}_{2}$, and in the mineral fertilization 0-300-300-600 kg ha-1 of $\mathrm{N}-\mathrm{P}_{2} \mathrm{O}_{5}-\mathrm{K}_{2} \mathrm{O}$, with lowest value at $\mathrm{S}_{2}$.

In the first and second production cycles, the height of cactus pear cv. Gigante was greater at the spacing $\mathrm{S}_{1}$ (Table 2), similar to the results found by Sales et al. (2013), Donato et al. (2014a) and Silva et al. (2016), who obtained greater height in less dense plantations. Cladode length was greater at spacing $S_{1}$ in the first cycle and similar in the second cycle, while cladode width in the second cycle was greater at spacing $S_{1}$ and, in the third, smaller in $\mathrm{S}_{3}$.

The number of cladodes in the second cycle was higher at the spacing $S_{1}$ compared to $S_{3}$ and, in the third cycle, lower at the spacing $\mathrm{S}_{3}$ (Table 2).

Cladode area index in the first and second cycles was higher at spacing $\mathrm{S}_{3}$ compared to $\mathrm{S}_{1}$ and, in the third cycle, was lower at spacing $\mathrm{S}_{1}$ (Table 2 ). DM content in the first cycle was higher at the spacing $\mathrm{S}_{3}$; DMY in the first and third cycles was higher at spacing $\mathrm{S}_{3}$, whereas in the second cycle, it was higher at the spacing $S_{1}$ compared to $S_{3}$, agreeing with Donato et al. (2014a), who found higher DMY at the spacing with greater distance between plants.

Highest values of DM in the first cycle were recorded in the absence of fertilization and with manure application of $30 \mathrm{Mg} \mathrm{ha}^{-1}$ (Table 3). These results agree with those of Silva et al. (2013) and Barros et al. (2016), who observed reduction of DM with increased fertilization, justifiable by the greater number of cladodes (Table 1), more tender. In the second cycle, DM was higher without fertilization and with fertilizations using $90 \mathrm{Mg} \mathrm{ha}^{-1}$ of manure without and with addition of potassium and, in the third cycle, in the absence of fertilization and with fertilizations using $60 \mathrm{Mg} \mathrm{ha}^{-1}$ of manure combined with $300-300 \mathrm{~kg} \mathrm{ha}^{-1}$ of $\mathrm{P}_{2} \mathrm{O}_{5}-\mathrm{K}_{2} \mathrm{O} ; 90 \mathrm{Mg} \mathrm{ha}^{-1}$ of manure without and with addition of potassium, and mineral fertilization with $300-300-600 \mathrm{~kg} \mathrm{ha}^{-1}$ of $\mathrm{N}-\mathrm{P}_{2} \mathrm{O}_{5}-\mathrm{K}_{2} \mathrm{O}$.

These results are close to those reported by Donato et al. (2014b), who observed at $1.0 \times 0.5 \mathrm{~m}$ spacing the same DM content in the absence of fertilization and with fertilization of up to $90 \mathrm{Mg} \mathrm{ha}^{-1}$ of manure. On mean, DM content decreased by $32.54 \%$ from the first to the second cycle and by $37.50 \%$ from the first to the third cycle. The highest reductions were 40.99 and $48.21 \%$ in the absence of fertilization and 46.44 and $48.86 \%$ with manure application $30 \mathrm{Mg} \mathrm{ha}^{-1}$, from the first to the second cycle and from the first to the third cycle, respectively. These results agree with those of Donato et al. (2017c) and confirm that fertilizations with greater nutrient supply promote

Table 2. Structural characteristics of cactus pear cv. Gigante cultivated at different Spacings in three production cycles, 20112013, 2013-2014 and 2014-2015

\begin{tabular}{|c|c|c|c|c|c|}
\hline \multirow[b]{2}{*}{ Treatments } & \multirow[b]{2}{*}{$\begin{array}{c}\text { Characteristics } \\
\text { evaluated }\end{array}$} & \multicolumn{4}{|c|}{ Spacings } \\
\hline & & $\begin{array}{c}S_{1} \\
(3.0 \times 1.0 \times 0.2 \mathrm{~m})\end{array}$ & $(3.0 \times 1.0 \times 0.16 \mathrm{~m})$ & $(3.0 \times 1.0 \times 0.125 \mathrm{~m})$ & CV $(\%)$ \\
\hline \multirow{5}{*}{$\begin{array}{c}\text { Cycle I - 2011- } \\
2013\end{array}$} & CLL (cm) & $29.7 \mathrm{a}$ & $28.7 b$ & $28.40 \mathrm{~b}$ & 5.7 \\
\hline & $\mathrm{PH}$ (cm) & $112.0 \mathrm{a}$ & $103.3 \mathrm{~b}$ & $95.90 \mathrm{~b}$ & 11.4 \\
\hline & $\mathrm{CAl}\left(\mathrm{m}^{2}\right)$ & $3.1 \mathrm{~b}$ & $3.2 a b$ & $3.50 \mathrm{a}$ & 22.6 \\
\hline & $\mathrm{DM}\left(\mathrm{g} \mathrm{kg}^{-1}\right)$ & $91.2 \mathrm{~b}$ & $107.8 \mathrm{~b}$ & $129.20 \mathrm{a}$ & 23.3 \\
\hline & DMY (Mg ha-1) & $14.2 \mathrm{~b}$ & $12.2 b$ & $17.76 \mathrm{a}$ & 30.0 \\
\hline \multirow{6}{*}{$\begin{array}{c}\text { Cycle II - } \\
\text { 2013-2014 }\end{array}$} & CLL (cm) & $30.8 \mathrm{a}$ & $29.3 \mathrm{a}$ & $29.10 \mathrm{a}$ & 6.5 \\
\hline & CLW (cm) & $16.8 \mathrm{a}$ & $14.7 b$ & $14.60 \mathrm{~b}$ & 6.9 \\
\hline & $\mathrm{PH}(\mathrm{cm})$ & $116.1 \mathrm{a}$ & $93.3 \mathrm{~b}$ & $92.10 \mathrm{~b}$ & 11.5 \\
\hline & NCL (cm) & $15.8 \mathrm{a}$ & $14.5 \mathrm{ab}$ & $12.40 \mathrm{~b}$ & 23.1 \\
\hline & $\mathrm{CAl}\left(\mathrm{m}^{2}\right)$ & $2.9 \mathrm{~b}$ & $3.3 a b$ & $3.70 \mathrm{a}$ & 29.6 \\
\hline & DMY (Mg ha-1) & $17.0 \mathrm{a}$ & $15.0 \mathrm{ab}$ & $12.40 \mathrm{~b}$ & 34.0 \\
\hline \multirow{4}{*}{$\begin{array}{l}\text { Cycle III - } \\
2014-2015\end{array}$} & CLW (cm) & $16.9 \mathrm{a}$ & $16.7 \mathrm{a}$ & $16.20 \mathrm{~b}$ & 5.8 \\
\hline & NCL (un) & $14.1 \mathrm{a}$ & $13.4 \mathrm{a}$ & $11.00 \mathrm{~b}$ & 26.1 \\
\hline & $\mathrm{CAl}\left(\mathrm{m}^{2}\right)$ & $2.6 \mathrm{~b}$ & $3.9 \mathrm{a}$ & $4.20 \mathrm{a}$ & 25.8 \\
\hline & DMY $\left(\mathrm{Mg} \mathrm{ha}^{-1}\right)$ & $15.8 \mathrm{~b}$ & $17.8 \mathrm{~b}$ & $21.80 \mathrm{a}$ & 27.0 \\
\hline
\end{tabular}

CLL - Cladode length; PH - Plant height; CLW - Cladode width; NCL - Number of cladodes; CAI - Cladode area index; DM - Dry mass content; DMY - Dry mass yield

Means followed by the same lowercase letter in the line do not differ significantly by Tukey test $(\mathrm{p}<0.05)$ 
Table 3. Dry mass content (DM), green mass yield (GMY), dry mass yield (DMY) and rainwater use efficiency based on the dry mass of cactus pear cv. Gigante cultivated under mineral, organomineral and organic fertilization, in three production cycles, 2011-2015

\begin{tabular}{|c|c|c|c|c|c|c|c|c|c|c|c|c|}
\hline \multirow{3}{*}{ Fertilizations } & \multicolumn{3}{|c|}{ DM content ( $\left(\mathrm{kg}^{-1}\right)$} & \multicolumn{3}{|c|}{ GMY (Mg ha-1 cycle-1) } & \multicolumn{3}{|c|}{ DMY (Mg hä cycle-1) } & \multicolumn{3}{|c|}{$\begin{array}{l}\text { Rainwater use efficiency based } \\
\left.\text { on DMY (kg ha' } \mathrm{mm}^{-1}\right)\end{array}$} \\
\hline & \multicolumn{12}{|c|}{ Production cycles } \\
\hline & $1^{\text {st }}$ & $2^{\text {nd }}$ & $3^{\text {rd }}$ & $1^{\mathrm{st}}$ & $2^{\text {nd }}$ & $3^{\text {rd }}$ & $1^{\text {st }}$ & $2^{\text {nd }}$ & $3^{\text {rd }}$ & $1^{\text {st }}$ & $2^{\text {nd }}$ & $3^{\text {rd }}$ \\
\hline 1 & $137.1 \mathrm{a}$ & $80.9 \mathrm{a}$ & $71.0 \mathrm{a}$ & $73.7 \mathrm{~b}$ & $97.7 \mathrm{C}$ & $116.5 d$ & $9.3 \mathrm{c}$ & $7.9 \mathrm{c}$ & $8.2 \mathrm{~d}$ & $10.2 \mathrm{C}$ & $9.2 \mathrm{C}$ & $9.3 \mathrm{~d}$ \\
\hline 2 & $109.6 \mathrm{~b}$ & $67.5 \mathrm{~b}$ & $68.1 \mathrm{~b}$ & $153.0 \mathrm{a}$ & $198.2 \mathrm{~b}$ & 242.2 b & $16.2 \mathrm{a}$ & $13.5 \mathrm{~b}$ & $16.6 b$ & $17.7 \mathrm{a}$ & $15.8 \mathrm{~b}$ & $18.8 \mathrm{~b}$ \\
\hline 3 & $100.1 \mathrm{~b}$ & $57.5 \mathrm{c}$ & $74.6 \mathrm{a}$ & $177.0 \mathrm{a}$ & $225.3 \mathrm{a}$ & $286.0 \mathrm{~b}$ & $16.7 \mathrm{a}$ & $12.7 \mathrm{~b}$ & $21.5 \mathrm{a}$ & $18.3 \mathrm{a}$ & $14.9 \mathrm{~b}$ & $24.4 \mathrm{a}$ \\
\hline 4 & $132.0 \mathrm{a}$ & $70.7 \mathrm{~b}$ & $67.5 \mathrm{~b}$ & $97.9 \mathrm{~b}$ & $175.3 b$ & $199.4 \mathrm{C}$ & $12.4 \mathrm{~b}$ & $12.3 \mathrm{~b}$ & $13.1 \mathrm{C}$ & $13.6 \mathrm{~b}$ & $14.4 \mathrm{~b}$ & $14.9 \mathrm{c}$ \\
\hline 5 & $101.5 b$ & $74.2 \mathrm{~b}$ & $68.4 \mathrm{~b}$ & $158.4 \mathrm{a}$ & $208.8 b$ & $262.6 \mathrm{~b}$ & $15.8 \mathrm{a}$ & $15.4 \mathrm{a}$ & $18.3 b$ & $17.3 \mathrm{a}$ & $18.1 \mathrm{a}$ & $20.8 \mathrm{~b}$ \\
\hline 6 & $103.4 b$ & $69.1 \mathrm{~b}$ & $67.8 \mathrm{~b}$ & $156.4 \mathrm{a}$ & $203.3 b$ & $300.0 \mathrm{a}$ & $15.6 \mathrm{a}$ & $13.6 \mathrm{a}$ & $20.4 \mathrm{a}$ & $17.1 \mathrm{a}$ & $16.0 \mathrm{a}$ & $23.2 \mathrm{a}$ \\
\hline 7 & $110.1 \mathrm{~b}$ & $74.6 \mathrm{~b}$ & $65.9 \mathrm{~b}$ & $137.8 \mathrm{a}$ & $179.1 \mathrm{~b}$ & 267.8 b & $14.5 \mathrm{a}$ & $12.8 \mathrm{~b}$ & $17.6 \mathrm{~b}$ & $15.9 \mathrm{a}$ & $15.0 \mathrm{~b}$ & $20.0 \mathrm{~b}$ \\
\hline 8 & $100.1 b$ & $74.0 \mathrm{~b}$ & $71.8 \mathrm{a}$ & $175.2 \mathrm{a}$ & $232.8 \mathrm{a}$ & $286.1 \mathrm{~b}$ & $16.6 \mathrm{a}$ & $17.1 \mathrm{a}$ & $20.5 a$ & $18.2 \mathrm{a}$ & $20.0 \mathrm{a}$ & $23.3 \mathrm{a}$ \\
\hline 9 & $96.5 \mathrm{~b}$ & $66.9 \mathrm{~b}$ & $61.6 \mathrm{~b}$ & $162.4 \mathrm{a}$ & $267.9 \mathrm{a}$ & $346.8 \mathrm{a}$ & $15.1 \mathrm{a}$ & $17.5 \mathrm{a}$ & $21.2 \mathrm{a}$ & $16.5 \mathrm{a}$ & $20.5 \mathrm{a}$ & $24.2 \mathrm{a}$ \\
\hline 10 & $107.3 b$ & $81.3 \mathrm{a}$ & $69.5 \mathrm{a}$ & $136.0 \mathrm{a}$ & $238.6 \mathrm{a}$ & $306.3 \mathrm{a}$ & $14.1 \mathrm{a}$ & $18.6 \mathrm{a}$ & $21.1 \mathrm{a}$ & $15.4 \mathrm{a}$ & $21.8 \mathrm{a}$ & $24.0 \mathrm{a}$ \\
\hline 11 & $112.6 b$ & $91.4 \mathrm{a}$ & $64.8 \mathrm{~b}$ & $136.2 \mathrm{a}$ & $242.8 \mathrm{a}$ & $307.7 \mathrm{a}$ & $15.2 \mathrm{a}$ & $22.0 \mathrm{a}$ & $19.9 \mathrm{a}$ & $16.6 \mathrm{a}$ & $25.7 \mathrm{a}$ & $22.6 \mathrm{a}$ \\
\hline 12 & $105.1 \mathrm{~b}$ & $79.3 \mathrm{a}$ & $71.1 \mathrm{a}$ & $150.5 \mathrm{a}$ & $247.8 \mathrm{a}$ & $321.5 \mathrm{a}$ & $15.0 \mathrm{a}$ & $19.3 \mathrm{a}$ & $23.2 \mathrm{a}$ & $16.4 \mathrm{a}$ & $22.7 \mathrm{a}$ & $26.4 \mathrm{a}$ \\
\hline CV (\%) & 23.3 & 21.7 & 13.2 & 33.4 & 23.5 & 21.4 & 30.0 & 34.0 & 27.0 & 30.0 & 34.0 & 27.0 \\
\hline
\end{tabular}

First cycle duration, 650 days (from planting to harvesting) and conduction between October 2011 and July 2013; Total rainfall in the period, 912.27 mm, corresponding to two rainy seasons - first one between October 2011 and February $2012(442.67 \mathrm{~mm}$ ) and second one between October 2012 and April 2013 (469.62 mm); Second cycle, period between two harvests, August 2013 to July 2014, with duration of 330 days; rainfall in the period, $853.96 \mathrm{~mm}$; Third cycle, period between two harvests, August 2014 to July 2015 , with duration of 330 days, rainfall in the period was $879.60 \mathrm{~mm} ; 12$ types of mineral, organomineral and organic fertilizations expressed in $\mathrm{Mg}^{-1}$ of bovine manure - $\mathrm{N}-\mathrm{P}_{2} \mathrm{O}-\mathrm{K}_{2} \mathrm{O}\left(\mathrm{kg}\right.$ ha ${ }^{-1}$ ); Fertilizations: (1)-0-000-000-000; (2)-0-300-300-300; (3)-0-300-300-600; (4)-30-000-000-000; (5)-30-150-000-300; (6)-30-150-300-600; (7)-60-000-000-000; (8)-60-000-300-300; (9)-60-000-300-600; (10)-90-000-000-000; (11)-90-000-000-300; (12)-90-000-000-600

Means followed by the same lowercase letter in the column do not differ significantly by Scott-Knott test $(\mathrm{p}<0.05)$

better plant growth, with emergence of new cladodes (Donato et al., 2014a; Silva et al., 2016), lower lignification of tissues and higher water accumulation (Donato et al., 2014b), which is accentuated in the second and third cycles, a consequence of the younger age of the cladodes, 330 days between harvests, compared to 650 days for the harvest in the first cycle. There is a dilution effect, in which the GMY promoted by the development in the favorable period is more intense than the DM production (Donato et al., 2014b).

For GMY, DMY and water use efficiency based on DMY, the lowest values were found without fertilization and with $30 \mathrm{Mg}$ ha $^{-1}$ of manure in most cases, whereas the highest values occurred in fertilizations with greater nutrient supply, particularly in organic fertilizations with $60 \mathrm{Mg} \mathrm{ha}^{-1}$ combined with potassium, $90 \mathrm{Mg} \mathrm{ha}^{-1}$ of manure with or without potassium addition, mineral fertilization with 300-300-600 kg ha-1 of N- $\mathrm{P}_{2} \mathrm{O}_{5}-\mathrm{K}_{2} \mathrm{O}$, or organomineral fertilization with $30 \mathrm{Mg} \mathrm{ha}^{-1}$ of manure and 150-300-600 kg ha-1 of N-P $\mathrm{O}_{5}-\mathrm{K}_{2} \mathrm{O}$.

There were mean increments of 46.81 and $89.11 \%$ for GMY, 3.60 and $25.49 \%$ for DMY and 10.67 and $30.18 \%$ for water use efficiency in cactus pear cv. Gigante, from the first to the second cycle and from the first to the third cycle, respectively. In general, for GMY, the highest increments occurred in fertilizations with greater nutrient supply, for instance, 72.78 and $121.54 \%$ from the first to the second and from the first to the third cycle, respectively, with $90 \mathrm{Mg} \mathrm{ha}^{-1}$ of bovine manure with or without potassium.

For DMY and water use efficiency, decreases were recorded in the absence of fertilization in both cycles, and from the first to the second production cycle in mineral fertilization, organomineral fertilization with $30 \mathrm{Mg} \mathrm{ha}^{-1}$ of manure combined with 150-300-600 kg ha-1 of N- $\mathrm{P}_{2} \mathrm{O}_{5}-\mathrm{K}_{2} \mathrm{O}$ and in organic fertilization with $60 \mathrm{Mg} \mathrm{ha}^{-1}$. The highest increments of DMY, 35.31 and $45.25 \%$, and water use efficiency, 44.57 and $50.69 \%$, from the first to the second and from the first to the third cycle, respectively, were observed in the fertilizations with $90 \mathrm{Mg} \mathrm{ha}^{-1}$ of manure with or without potassium addition.

Water use efficiency translates the species' capacity of adaptation to conditions of water restriction (Donato et al., 2017 c). This process is favored by the size of the source, which is the reserve left in the previous harvest represented by the primary cladodes (Lima et al., 2016), the root system already established, and the production of "rainfall" roots, which are roots produced to absorb water as soon as rain occurs, dying afterwards.

In general, in the absence of fertilizers, DMY was on mean 8.7 $\mathrm{Mg} \mathrm{ha}^{-1} \mathrm{cycle}^{-1}$ in the three cycles; water productivity was close to $10 \mathrm{~kg} \mathrm{ha}^{-1} \mathrm{~mm}^{-1}$ and the DM content decreased by more than $40 \%$, due to cladode age. By contrast, for the fertilization with the greatest nutrient supply, especially organic and organomineral, in the third production cycle, period of crop stabilization, DMY and water use efficiency were respectively higher than $20 \mathrm{Mg} \mathrm{ha}^{-1}$ and higher than $20 \mathrm{~kg} \mathrm{ha}^{-1} \mathrm{~mm}^{-1}$. These values demonstrate the importance of fertilization as a production factor, capable of increasing DM yield and water use efficiency in plants with CAM metabolism in rainfed cultivation in the Brazilian semiarid region (Donato et al., 2017c).

\section{Conclusions}

1. Dry mass content decreases, while green mass yield, dry mass yield and water use efficiency increase from the first to the third cycle.

2. It is feasible to use planting arrangements in triple or quadruple rows which allow favoring the mechanization index of cactus pear cv. Gigante.

3. Water use efficiency greater than $20 \mathrm{~kg} \mathrm{ha}^{-1} \mathrm{~mm}^{-1}$ and green mass and dry mass yields higher than 200 and $15 \mathrm{Mg} \mathrm{ha}^{-1} \mathrm{cycle}^{-1}$, respectively, in cactus pear cv. Gigante are ensured with application of about 300-300-300 kg ha-1 year ${ }^{-1}$ of $\mathrm{N}_{-} \mathrm{P}_{2} \mathrm{O}_{5}-\mathrm{K}_{2} \mathrm{O}$ using organic, organomineral or mineral sources. 


\section{Literature Cited}

Barros, J. L. de; Donato, S. L. R.; Gomes, V. M.; Donato, P. E. R.; Silva, J. A. da; Padilha Junior, M. C. Palma forrageira 'Gigante' cultivada com adubação orgânica. Revista Agrotecnologia, v.6, p.53-65, 2016. https://doi.org/10.12971/2179-5959/agrotecnologia.v7n1p53-65

Brasil. Instrução Normativa SDA - N 2 28, de 27 de julho de 2007. Brasília: Diário Oficial da República Federativa do Brasil, 2007. 149p. Seção 1

Cavalcante, L. A. D.; Santos, G. R. de A.; Silva, L. M. da; Fagundes, J. L.; Silva, M. A. da. Respostas de genótipos de palma forrageira a diferentes densidades de cultivo. Pesquisa Agropecuária Tropical, v.44, p.424-433, 2014. https://doi.org/10.1590/S1983-40632014000400010

Donato, P. E. R.; Donato, S. L. R.; Silva, J. A.; Londe, L. N. C.; Rodrigues, M. G. V. Implantação da lavoura de palma forrageira. Informe Agropecuário, v.38, p.21-33, 2017a.

Donato, P. E. R.; Pires, A. J. V.; Donato, S. L. R.; Bonomo, P.; Silva, J. A. da; Aquino, A. A. de. Morfometria e rendimento da palma forrageira 'Gigante' sob diferentes espaçamentos e doses de adubação orgânica. Revista Brasileira de Ciências Agrárias, v.9, p.151-158, 2014a. https://doi.org/10.5039/agraria.v9i1a3252

Donato, P. E. R.; Pires, A. J. V.; Donato, S. L. R.; Silva, J. A. da; Aquino, A. A. de. Valor nutritivo da palma forrageira 'Gigante' cultivada sob diferentes espaçamentos e doses de esterco bovino. Revista Caatinga, v.27, p.163-172, 2014 b.

Donato, P. E. R.; Silva, J. A. da; Donato, S. L. R.; Rodrigues, M. G. V.; Caxito, A. M. Índices técnicos, de produção e econômicos para a cultura da palma forrageira. Informe Agropecuário, v.38, p.97-106, $2017 \mathrm{~b}$.

Donato, S. L. R.; Arantes, A. M.; Brito, C. F. B.; Rodrigues, M. G. V.; Silva, J. A. da; Donato, P. E. R. Considerações sobre clima semiárido e ecofisiologia da palma forrageira. Informe Agropecuário, v.38, p.7-20, 2017c.

Lima, G. F. da C.; Rego, M. M. T.; Dantas, F. D. G.; Lôbo, R. N. B.; Silva, J. G. M. da; Aguiar, E. M. de. Morphological characteristics and forage productivity of irrigated cactus pear under different cutting intensities. Revista Caatinga, v.29, p.481-488, 2016. https:// doi.org/10.1590/1983-21252016v29n226rc

Mondragón-Jacobo, C.; Pérez-González, S. Germplasm resources and breeding Opuntia for fodder production. In: Mondragón-Jacobo, C.; Pérez-González, S. Cactus (Opuntia spp.) as forage. Rome: FAO, 2001. Chap.3, p.21-28.

Padilha Junior, M. C.; Donato, S. L. R.; Silva, J. A. da; Donato, P. E. R.; Souza, E. dos S. Características morfométricas e rendimento da palma forrageira 'Gigante' sob diferentes adubações e configurações de plantio. Revista Verde de Agroecologia e Desenvolvimento Sustentável, v.11, p.67-72, 2016. https://doi. org/10.18378/rvads.v11i1.3710
Pimienta-Barrios, E.; Hernández, J. Z.; Muñoz-Urias, A.; Murguía, C. R. Ecophysiology of young stems (cladodes) of Opuntia ficusindica in wet and dry conditions. Gayana Botanica, v.69, p.232239, 2012. https://doi.org/10.4067/S0717-66432012000200002

Pinto, M. S. C.; Menezes, R. S. C.; Sampaio, E. V. S. B.; Andrade, A. P.; Pimienta Filho, E. C.; Andrade, M. V. M.; Figueiredo, M. V. Estimativa do peso da palma forrageira (Opuntia ficus-indica, Mill.) a partir de medidas dos cladódios. In: Reunião Anual da Sociedade Brasileira de Zootecnia, 39, 2002, Recife. Anais... Recife: SBZ, 2002. p.54-64.

Ramos, J. P. de F.; Leite, M. L. de M. V.; Oliveira Junior, S. de; Nascimento, J. P. do; Santos, E. M. Crescimento vegetativo de Opuntia ficus-indica em diferentes espaçamentos de plantio. Revista Caatinga, v.24, p.41-48, 2011.

Sales, A. T.; Leite, M. L. de M. V.; Alves, A. Q.; Ramos, J. P. de F.; Nascimento, J. P. do. Crescimento vegetativo de palma forrageira em diferentes densidades de plantio no Curimatú Paraibano. Tecnologia \& Ciência Agropecuária, v.7, p.19-24, 2013.

Silva, D. J.; Queiroz, A. C. Análise de alimentos: Métodos químicos e biológicos. 3.ed. Viçosa: Editora UFV, 2009. 235p.

Silva, J. A. da; Bonomo, P.; Donato, S. L. R.; Pires, A. J. V.; Rosa, R. C. C.; Donato, P. E. R. Composição mineral em cladódios de palma forrageira sob diferentes espaçamentos e adubações química. Revista Brasileira de Ciências Agrárias, v.7, p.866-875, 2012. https://doi.org/10.5039/agraria.v7isa2134

Silva, J. A. da; Bonomo, P.; Donato, S. L. R.; Pires, A. J. V.; Silva, F. F.; Donato, P. E. R. Composição bromatológica de cladódios de palma forrageira sob diferentes espaçamentos e adubações químicas. Revista Brasileira de Ciências Agrárias, v.8, p.342-350, 2013. https://doi.org/10.5039/agraria.v8i2a2431

Silva, J. A. da; Donato, S. L. R.; Donato, P. E. R.; Souza, E. dos S.; Padilha Junior, M. C.; Silva Júnior, A. A. e. Yield and vegetative growth of cactus pear at different spacings and under chemical fertilizations. Revista Brasileira de Engenharia Agrícola e Ambiental, v.20, p.564-569, 2016. https://doi.org/10.1590/18071929/agriambi.v20n6p564-569

Silva, M. L. da; Fagundes, J. L.; Viegas, P. A. A.; Muniz, E. N.; Rangel, J. H. de A.; Moreira, A. L.; Backes, A. A. Produtividade da palma forrageira cultivada em diferentes densidades de plantio. Ciência Rural, v.44, p.2064-2061, 2014. https://doi.org/10.1590/0103$8478 \mathrm{cr} 20131305$

Silva, N. G. de M. e; Lira, M. de A.; Santos, M. V. F. dos; Dubeux Júnior, J. C. B.; Mello, A. C. L. de; Silva, M. da C. Relação entre características morfológicas e produtivas de clones de palmaforrageira. Revista Brasileira de Zootecnia, v.39, p.2389-2397, 2010. https://doi.org/10.1590/S1516-35982010001100011 